\title{
Synthesis, Characterization and Antimicrobial Activity of Imidazole Derivatives Based on 2-chloro-7- methyl-3-formylquinoline
}

\author{
R. H. PARAB* and B. C. DIXIT \\ Chemistry Department, V.P. \& R.P.T.P Science College, Vallabh Vidyanagar-388120, India \\ parabr@rocketmail.com \\ Received 19 October 2011; Accepted 30 December 2011

\begin{abstract}
A series of oxazole and thereof imidazole derivatives were prepared from 2-chloro-7-methyl-3-formyl quinoline. The structures of all synthesized compounds were elucidated by elemental, IR, ${ }^{1} \mathrm{HNMR},{ }^{13} \mathrm{CNMR}$ spectra. Supplementary to these, they were assayed in vitro for their antimicrobial activity; it was revealed that some synthesized derivatives were exhibiting competent biological activity against both gram negative \& gram positive bacterial species and fungal microorganisms.
\end{abstract}

Keywords: Quinoline, Imidazole, Antibacterial activity.

\section{Introduction}

Heterocyclic compounds of nitrogen containing five membered ring systems have been described for their biological activity against various micro organisms. ${ }^{1,2}$ Besides this, the chemistry of quinoline and imidazoles have also been reviewed in literature. A number of derivatives of quinoline serve as valuable therapeutic agents. ${ }^{1-5}$ Considerable interest has been created in the chemistry of quinoline derivatives due to their versatile therapeutic activities like bactericidal, antihistaminic, antimalarial, antidepressant, analgesic, anti-ulcer, antiviral, herbicidal, antitumor, anti-allergic, anticonvulsant, anti-inflammatory etc. ${ }^{6-9}$ Almost every class of imidazole derivatives has been used for different reactions to produce enormous number of heterocycles. Later, in the last three decades many scientists have synthesized various imidazole heterocyclic precursors containing active hydrogen atom on nitrogen and evaluated in terms of their pharmacological activity. ${ }^{10-15}$ The emergence of powerful and elegant imidazole has stimulated major advances in chemotherapeutic agents of remarkable significance in medicine, biology and pharmacy. Besides this, it is also reported $^{15-16}$ that imidazole compounds are one of the effective antifungal agents. Considering the importance of both moieties Quinoline and Imidazole, extending our previous work $^{17,18}$ we planned to synthesize imidazole derivatives from 2-chloro-7-methyl3 -formylquinoline. The whole synthesis route is shown in scheme 1. 


\section{Material and Methods}

Acetanilide and their derivatives were purified by crystallization in R-spirit. DMF and phosphorous oxychloride used were of analytical reagent grade. All of the organic solvents and Hippuric acid, acetic anhydride, sodium acetate used were of analytical reagent grade. Eight diamines were used after recrystallization. The 2-chloro-7-methyl-3-formyl quinoline was synthesized by Vilsmeier-Haack reaction by the procedure reported in the literature. ${ }^{16,19}$ Melting points were measured in an open capillary tube and are uncorrected. Elemental analysis was obtained using Perkin Elmer (USA) 2400, series II CHN-analyser. In addition to this, the nitrogen content in all the imidazoles was estimated by Kjeldhal's method. ${ }^{20}$ IR spectra were recorded on a NICOLET-400 D spectrophotometer, ${ }^{1} \mathrm{H}$ NMR spectra in $\mathrm{CDCl}_{3} / \mathrm{DMSO}-d_{6}$ at $400 \mathrm{MHz}$ on a FT-NMR, R-1500 spectrometer (chemical shift in $\delta$ ppm) relative to TMS as an internal standard. Reactions were monitored by TLC, using silica gel as an adsorbent and ethyl acetate-hexane in different ratios as eluent.

\section{Experimental}

\section{Synthesis of 2-chloro-7-methyl-3-formylquinoline}

The 2-chloro-7-methyl-3-formylquinoline was synthesized by Vilsmeier-Haack Reaction by the procedure reported in the literature ${ }^{16,19-24}$.

Dimethyl formamide $(9.6 \mathrm{ml}, 0.125 \mathrm{M})$ at $0{ }^{0} \mathrm{C}$ was taken in a three necked flask equipped with a drying tube and phosphoryl oxychloride $(32.2 \mathrm{ml}, 0.35 \mathrm{M})$ was added drop wise under continuous stirring. To this solution, 3-methyl acetanilide $(0.05 \mathrm{M})$ was slowly added with continuous stirring. After five minutes, solution was heated under reflux for 1 hour at $80-90{ }^{0} \mathrm{C}$. The reaction mixture was poured into ice water $(300 \mathrm{ml})$ and stirred for further $30 \mathrm{mins}$ at $0-10{ }^{0} \mathrm{C}$. The 2-chloro-7-methyl-3-formylquinoline so obtained, was filtered and washed with water. It was crystallized using R-spirit. The yield was $82 \%$.

\section{(5Z)-3-(3-aminophenyl)-5-[(2-chloro-7-methyl-3-quinolinyl)methylene]-2-phenyl- 3,5-dihydro-4H-imidazol-4-one (IMMD)}

(5Z)-3-(3-aminophenyl)-5-[(2-chloro-7-methyl-3-quinolinyl)methylene]-2-phenyl-3,5dihydro $-4 H$-imidazol-4-one (IMMD) was prepared by refluxing benzoyl glycine (hippuric acid) and $(0.25 \mathrm{~mol})$ 2-chloro-7-methyl-3-formyl quinoline $(0.25 \mathrm{~mol})$ in acetic anhydride $(0.75 \mathrm{~mol})$ with freshly prepared sodium acetate $(0.25 \mathrm{~mol})$ for $2 \mathrm{~h}$ (Erlenmeyer Oxazole Condensation). After cooling, ethanol $(10 \mathrm{ml})$ was added and was kept overnight at $5^{\circ} \mathrm{C}$. The solid obtained was filtered, washed with alcohol, dried in vacuum and recrystallized by using benzene. As a result ((4Z)-4-[(2-chloro-7-methyl-3-quinolinyl)methylene]-2-phenyl1,3-oxazol-5(4H)-one was separated out.

The synthesized ((4Z)-4-[(2-chloro-7-methyl-3-quinolinyl)methylene]-2-phenyl-1,3oxazol-5 $(4 H)$-one $(0.01 \mathrm{M})$ was added to a solution of m-phenylene diamine $(0.01 \mathrm{M})$ in 20 $\mathrm{ml}$ ethyl alcohol containing few drops of glacial acetic acid and the mixture was heated and was later on cooled down. The solid mass, thus obtained was separated and was recrystallized by using methanol which can be designated as (5Z)-3-(3-aminophenyl)-5-[(2-chloro-7-methyl-3quinolinyl) methylene]-2-phenyl-3,5-dihydro-4H-imidazol-4-one (IMMD). The other 2-chloro 7methyl-3-formylquinoline based imidazole derivatives were synthesized in a similar manner by using remaining seven different diamines. ${ }^{25,26}$ 
<smiles>Cc1ccc2cc(C=O)c(Cl)nc2c1</smiles>

2-chloro-7-methyl-3-formyl quinoline Hippuric acid<smiles></smiles>

Where,
$\mathrm{R}, \mathrm{R}_{2}=\mathrm{H}, \mathrm{R}_{1}=\mathrm{NH}_{2}$ :
IMMD
$\mathrm{R}_{1}=\mathrm{R}_{2}=\mathrm{H} \quad \mathrm{R}=\mathrm{C}_{6} \mathrm{H}_{4} \mathrm{SO}_{2}-\mathrm{NH}_{2}:$ IMDS
$\mathrm{R}_{1}, \mathrm{R}_{2}=\mathrm{H}, \mathrm{R}=\mathrm{NH}_{2}$ :
IMPD
$\mathrm{R}_{1}, \mathrm{R}_{2}=\mathrm{H} \mathrm{R}=\mathrm{C}_{7} \mathrm{H}_{6}-\mathrm{NH}_{2}$ :
IMDM
$\mathrm{R}_{1}, \mathrm{R}_{2}=\mathrm{H}, \mathrm{R}=\mathrm{C}_{6} \mathrm{H}_{4}-\mathrm{NH}_{2}: \quad$ IMBD
$\mathrm{R}_{1}=\mathrm{R}_{2}=\mathrm{H} \quad \mathrm{R}=\mathrm{C}_{6} \mathrm{H}_{5} \mathrm{SO}_{2}-\mathrm{NH}_{2}:$ IMDA
$\mathrm{R}_{1}=\mathrm{H}, \mathrm{R}_{2}=\mathrm{CH}_{3} \mathrm{R}=\mathrm{C}_{7} \mathrm{H}_{6}-\mathrm{NH}_{2}:$ IMOTD $\mathrm{R}_{1}=\mathrm{NH}_{2}, \mathrm{R}_{2}=\mathrm{H}, \mathrm{R}=\mathrm{CH}_{3}$ :
IMDT

Scheme 1 Reaction protocol of 2-chloro-7-methyl-3-formyl quinoline based imidazole derivatives. 
Antimicrobial assay: The antimicrobial activities were determined using agar-cup method by measuring the zone of inhibition in $\mathrm{mm}$. All newly synthesized compounds were screened in vitro for their antibacterial activity against Gram positive species (Bacillus subtilis, Bacillus megaterium) and Gram negative species (Escherichia coli, Pseudomonas aeruginosa), while antifungal activity was tested against Aspergillus niger and C. albicans at concentration of $75 \mu \mathrm{g} / \mathrm{ml}$. Streptomycin was used as a standard drug for antibacterial screening, while Imidil was used as a standard drug for antifungal screening and solvent DMSO was used as a control. Each experiment was made in triplicate and the average reading was taken. The results are summarized in Table-3.

\section{Synthesis, characterization and antimicrobial activity of imidazole derivatives based on 2-chloro-7-methyl-3-formylquinoline}

The test was performed by using the agar cup borer method, with some modifications using Streptomycin and Imidil as reference for bacterial and fungal culture respectively. ${ }^{27} \mathrm{~A}$ test tube containing sterile melted top agar $(1.5 \%)$ previously cooled at room temperature with $0.2 \mathrm{ml}$ suspension of the test culture, mixed methodically and poured in the petri dish containing sterile base agar medium (autoclaved at $121^{\circ} \mathrm{C}$ for $15 \mathrm{~min}$.) then allowed it to solidify. The cup borer was sterilized by dipping into absolute ethanol and flaming it then allowed to cool it. With the help of sterile cup-borer, three cups in the agar-plate were marked and were injected with $0.1 \mathrm{ml}$ of test solution, $0.1 \mathrm{ml}$ of standard solution and $0.1 \mathrm{ml}$ of DMSO solvent respectively. Then the plates were allowed to diffuse for $20 \mathrm{~min}$. in refrigerator at $4-5^{\circ} \mathrm{C}$. The plates were then incubated in upright position at $37^{\circ} \mathrm{C}$ for $24 \mathrm{hrs}$. After incubation, the relative susceptibility of the micro-organisms to the potential antimicrobial agent is demonstrated by a clear zone of growth inhibition around the cup. The inhibition zone caused by the various compounds on the micro-organisms was measured and the activity was rated on the basis of the size of the inhibition zone.

\section{Results and Discussion}

The elemental analysis of the prepared compounds is given in Table-1. Where,

\begin{tabular}{|c|c|c|c|}
\hline $\begin{array}{l}\text { Heterocyclic } \\
\text { substrate }\end{array}$ & Diamines & IUPAC name & Code \\
\hline \multirow{5}{*}{$\begin{array}{l}\text { 2-chloro-7- } \\
\text { methyl-3- } \\
\text { formylquinoline }\end{array}$} & MPD & $\begin{array}{l}\text { (5Z)-3-(3-aminophenyl)-5-[(2-chloro-7-methyl- } \\
\text { 3-quinolinyl)methylene]-2-phenyl-3,5-dihydro- } \\
\text { 4H-imidazol-4-one }\end{array}$ & IMMD \\
\hline & PPD & $\begin{array}{l}\text { (5Z)-3-(4-aminophenyl)-5-[(2-chloro-7-methyl- } \\
\text { 3-quinolinyl)methylene]-2-phenyl-3,5-dihydro- } \\
\text { 4H-imidazol-4-one }\end{array}$ & IMPD \\
\hline & $\mathrm{BD}$ & $\begin{array}{l}\text { (5Z)-3-(4'-amino[1,1'-biphenyl]-4-yl)-5-[(2- } \\
\text { chloro-7-methyl-3-quinolinyl)methylene]-2- } \\
\text { phenyl-3,5-dihydro-4H-imidazol-4-one }\end{array}$ & IMBD \\
\hline & OTD & $\begin{array}{l}\text { (5Z)-3-(4'-amino-3,3'-dimethyl[1,1'-biphenyl]- } \\
\text { 4-yl)-5-[(2-chloro-7-methyl-3- } \\
\text { quinolinyl)methylene]-2-phenyl-3,5-dihydro- } \\
\text { 4H-imidazol-4-one }\end{array}$ & IMOTD \\
\hline & DDS & $\begin{array}{l}\text { (5Z)-3-\{4-[(4-aminophenyl)sulfonyl]phenyl }\}-5- \\
{[(2-\text { chloro-7-methyl-3-quinolinyl)methylene]-2- }}\end{array}$ & IMDS \\
\hline
\end{tabular}




\begin{tabular}{|l|l|l|l|}
\hline & & phenyl-3,5-dihydro-4H-imidazol-4-one & \\
\cline { 2 - 4 } & DDM & $\begin{array}{l}\text { (5Z)-3-[4-(4-aminobenzyl)phenyl]-5-[(2-chloro- } \\
\text { 7-methyl-3-quinolinyl)methylene]-2-phenyl- } \\
\text { 3,5-dihydro-4H-imidazol-4-one }\end{array}$ & IMDM \\
\cline { 2 - 4 } & DASA & $\begin{array}{l}\text { N-(4-aminophenyl)-4-\{(4Z)-4-[2-chloro-7- } \\
\text { methyl-3-quinolinyl)methylene]-5-oxo-2- } \\
\text { phenyl-4,5-dihydro-1H-imidazol-1- } \\
\text { yl benzenesulfonamide }\end{array}$ & IMDA \\
& $\begin{array}{l}\text { (5Z)-3-(5-amino-2-methylphenyl)-5-[(2-chloro- } \\
\text { 7-methyl-3-quinolinyl)methylene]-2-phenyl- } \\
\text { 3,5-dihydro-4H-imidazol-4-one }\end{array}$ & IMDT \\
\cline { 2 - 4 } & DT & & \\
& &
\end{tabular}

Table 1. Elemental analysis of imidazoles based on 2-chloro-7-methyl-3-formylquinoline.

\begin{tabular}{|c|c|c|c|c|c|c|c|c|c|}
\hline \multirow{2}{*}{$\begin{array}{c}\text { Imidazole } \\
\text { code }\end{array}$} & \multirow{2}{*}{$\begin{array}{c}\text { Molecular } \\
\text { Formula }\end{array}$} & \multirow{2}{*}{$\begin{array}{c}\text { MW } \\
\text { g/mol }\end{array}$} & \multicolumn{2}{|c|}{ \%C } & \multicolumn{2}{|c|}{ \%H } & \multicolumn{3}{c|}{ \%N } \\
\cline { 5 - 10 } & & & Calc. & Found & Calc. & Found & Calc. & Found & Found* \\
\hline IMMD & $\mathrm{C}_{26} \mathrm{H}_{19} \mathrm{ClN}_{4} \mathrm{O}$ & 438 & 71.15 & 71.12 & 4.36 & 4.30 & 12.76 & 12.70 & 12.71 \\
\hline IMPD & $\mathrm{C}_{26} \mathrm{H}_{19} \mathrm{ClN}_{4} \mathrm{O}$ & 438 & 71.15 & 71.14 & 4.36 & 4.31 & 12.76 & 12.70 & 12.72 \\
\hline IMBD & $\mathrm{C}_{23} \mathrm{H}_{23} \mathrm{ClN}_{4} \mathrm{O}$ & 514 & 74.63 & 74.60 & 4.50 & 4.45 & 10.88 & 10.81 & 10.88 \\
\hline IMOTD & $\mathrm{C}_{34} \mathrm{H}_{27} \mathrm{ClN}_{4} \mathrm{O}$ & 542 & 75.20 & 75.19 & 5.01 & 5.00 & 10.32 & 10.30 & 10.31 \\
\hline IMDS & $\mathrm{C}_{32} \mathrm{H}_{23} \mathrm{ClN}_{4} \mathrm{O}_{3} \mathrm{~S}$ & 578 & 66.37 & 66.30 & 4.00 & 4.02 & 9.68 & 9.60 & 9.65 \\
\hline IMDM & $\mathrm{C}_{33} \mathrm{H}_{25} \mathrm{ClN}_{4} \mathrm{O}$ & 528 & 74.92 & 74.90 & 4.76 & 4.70 & 10.59 & 10.55 & 10.59 \\
\hline IMDA & $\mathrm{C}_{32} \mathrm{H}_{24} \mathrm{ClN}_{5} \mathrm{O}_{3} \mathrm{~S}$ & 593 & 64.70 & 64.68 & 4.07 & 4.05 & 11.79 & 11.75 & 11.79 \\
\hline IMDT & $\mathrm{C}_{27} \mathrm{H}_{21} \mathrm{ClN}_{4} \mathrm{O}$ & 452 & 71.60 & 71.58 & 4.67 & 4.65 & 12.37 & 12.35 & 12.31 \\
\hline
\end{tabular}

* Found by the Kjeldhal's Method

MW $=$ Molecular Weight

In all the imidazole derivatives vinylic proton is seen around $6 \mathrm{ppm}(\delta)$. The aromatic protons are assigned to resonances in the range of $(\delta) 7.00$ to $8.2 \mathrm{ppm}$. The resonance due to $-\mathrm{NH}_{2}$ moiety is attributed to the peak in the range of 6.5 to $6.8 \mathrm{ppm}$. The resonance due to $\mathrm{CH}_{3}$ is observed at 2-2.2 ppm. The compounds containing 4,4'-diamino diphenyl methane has a $>\mathrm{CH}_{2}$ moiety attached to benzene ring and this $>\mathrm{CH}_{2}$ is highly deshielded. This is reflected in the proton NMR signal of $>\mathrm{CH}_{2}$ group seen at $3.69 \mathrm{ppm}$. The ${ }^{13} \mathrm{C}$ NMR peaks are quite interesting in all these imidazoles derivatives where the peak around $165 \mathrm{ppm}$ is attributed to $\mathrm{C}$ of $>\mathrm{C}=\mathrm{O}$ (Table-2). In all the compounds the peak at $158 \mathrm{ppm}$ is assigned to $\mathrm{Cl}-\mathrm{C}=\mathrm{N}$ moiety. The peak at $148 \mathrm{ppm}$ is likely due to $>\mathrm{C}=\mathrm{N}$ moiety. The peaks in the region 110-130 ppm are attributed to aromatic ring. The compounds containing 4,4'-diamino diphenyl methane shows a peak at $40 \mathrm{ppm}$ which is due to $=\mathrm{CH}_{2}$ group attached to both the rings. 
Table 2. Assignment of NMR $\left({ }^{1} \mathrm{H}\right.$ and $\left.{ }^{13} \mathrm{C}\right)$ peaks in imidazole derivatives of 2-chloro-7methyl-3-formyl quinoline.

\begin{tabular}{|c|c|c|c|c|}
\hline $\begin{array}{l}\text { Imidazole } \\
\text { code }\end{array}$ & $\begin{array}{l}\text { Peaks } \\
\text { observed ( } \delta) \\
\text { ppm }\end{array}$ & $\begin{array}{l}\text { Assignment }{ }^{1} \mathbf{H} \\
\text { NMR }\end{array}$ & 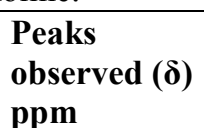 & $\begin{array}{l}\text { Assignment }{ }^{13} \mathrm{C} \\
\text { NMR }\end{array}$ \\
\hline IMMD & $\begin{array}{l}2.47 \\
6.03 \\
6.80 \\
7.10-8.42\end{array}$ & $\begin{array}{l}\mathrm{CH}_{3} \\
=\mathrm{CH} \text { Vinylic } \\
-\mathrm{NH}_{2} \\
\text { Aromatic Protons }\end{array}$ & $\begin{array}{l}165 \\
147 \\
157 \\
109-132 \\
18\end{array}$ & $\begin{array}{l}\mathrm{C}=\mathrm{O} \\
\mathrm{C}=\mathrm{N} \\
\mathrm{Cl}-\mathrm{C}=\mathrm{N} \\
\mathrm{C} \text { in aromatic ring } \\
\mathrm{CH}_{3}\end{array}$ \\
\hline IMPD & $\begin{array}{l}2.47 \\
6.0 \\
6.78 \\
7.2-8.42\end{array}$ & $\begin{array}{l}\mathrm{CH}_{3} \\
=\mathrm{CH} \text { Vinylic } \\
-\mathrm{NH}_{2} \\
\text { Aromatic Protons }\end{array}$ & $\begin{array}{l}165 \\
148 \\
158 \\
115-135 \\
17\end{array}$ & $\begin{array}{l}\mathrm{C}=\mathrm{O} \\
\mathrm{C}=\mathrm{N} \\
\mathrm{Cl}-\mathrm{C}=\mathrm{N} \\
\mathrm{C} \text { in aromatic ring } \\
\mathrm{CH}_{3}\end{array}$ \\
\hline IMBD & $\begin{array}{l}2.47 \\
5.7 \\
6.64 \\
7.2-8.42\end{array}$ & $\begin{array}{l}\mathrm{CH}_{3} \\
=\mathrm{CH} \text { Vinylic } \\
-\mathrm{NH}_{2} \\
\text { Aromatic Protons }\end{array}$ & $\begin{array}{l}165 \\
148 \\
157 \\
112-135 \\
18\end{array}$ & $\begin{array}{l}\mathrm{C}=\mathrm{O} \\
\mathrm{C}=\mathrm{N} \\
\mathrm{Cl}-\mathrm{C}=\mathrm{N} \\
\mathrm{C} \text { in aromatic ring } \\
\mathrm{CH}_{3}\end{array}$ \\
\hline IMOTD & $\begin{array}{l}2.14 \\
2.24 \\
2.47 \\
6.2 \\
6.38 \\
7.3-8.42 \\
\end{array}$ & $\begin{array}{l}\mathrm{CH}_{3} \\
\mathrm{CH}_{3} \\
\mathrm{CH}_{3} \\
=\mathrm{CH} \text { Vinylic } \\
-\mathrm{NH}_{2} \\
\text { Aromatic Protons }\end{array}$ & $\begin{array}{l}165 \\
147 \\
158 \\
110-135 \\
17 \\
18 \\
\end{array}$ & $\begin{array}{l}\mathrm{C}=\mathrm{O} \\
\mathrm{C}=\mathrm{N} \\
\mathrm{Cl}-\mathrm{C}=\mathrm{N} \\
\mathrm{C} \text { in aromatic ring } \\
\mathrm{CH}_{3} \\
\mathrm{CH}_{3}\end{array}$ \\
\hline IMDS & $\begin{array}{l}2.47 \\
6.0 \\
6.43 \\
7.2-8.38\end{array}$ & $\begin{array}{l}\mathrm{CH}_{3} \\
=\mathrm{CH} \text { Vinylic } \\
-\mathrm{NH}_{2} \\
\text { Aromatic Protons }\end{array}$ & $\begin{array}{l}165 \\
148 \\
158 \\
110-130 \\
18\end{array}$ & $\begin{array}{l}\mathrm{C}=\mathrm{O} \\
\mathrm{C}=\mathrm{N} \\
\mathrm{Cl}-\mathrm{C}=\mathrm{N} \\
\mathrm{C} \text { in aromatic ring } \\
\mathrm{CH}_{3}\end{array}$ \\
\hline IMDM & $\begin{array}{l}2.47 \\
3.69 \\
6.2 \\
6.42 \\
7.2-8.42\end{array}$ & $\begin{array}{l}\mathrm{CH}_{3} \\
\mathrm{CH}_{2} \\
=\mathrm{CH} \text { Vinylic } \\
-\mathrm{NH}_{2} \\
\text { Aromatic Protons }\end{array}$ & $\begin{array}{l}165 \\
148 \\
158 \\
115-135 \\
17 \\
40\end{array}$ & $\begin{array}{l}\mathrm{C}=\mathrm{O} \\
\mathrm{C}=\mathrm{N} \\
\mathrm{Cl}-\mathrm{C}=\mathrm{N} \\
\mathrm{C} \text { in aromatic ring } \\
\mathrm{CH}_{3} \\
\mathrm{CH}_{2}\end{array}$ \\
\hline IMDA & $\begin{array}{l}2.47 \\
6.25 \\
6.55 \\
6.64 \\
7.2-8.42\end{array}$ & $\begin{array}{l}\mathrm{CH}_{3} \\
=\mathrm{CH} \text { Vinylic } \\
\mathrm{NH} \\
-\mathrm{NH}_{2} \\
\text { Aromatic Protons }\end{array}$ & $\begin{array}{l}165 \\
148 \\
158 \\
112-132 \\
18\end{array}$ & $\begin{array}{l}\mathrm{C}=\mathrm{O} \\
\mathrm{C}=\mathrm{N} \\
\mathrm{Cl}-\mathrm{C}=\mathrm{N} \\
\mathrm{C} \text { in aromatic ring } \\
\mathrm{CH}_{3}\end{array}$ \\
\hline IMDT & $\begin{array}{l}2.47 \\
2.18 \\
6.03 \\
6.52 \\
7.2-8.42\end{array}$ & $\begin{array}{l}\mathrm{CH}_{3} \\
\mathrm{CH}_{3} \\
=\mathrm{CH} \text { Vinylic } \\
-\mathrm{NH}_{2} \\
\text { Aromatic Protons }\end{array}$ & $\begin{array}{l}165 \\
147 \\
156 \\
112-130 \\
17\end{array}$ & $\begin{array}{l}\mathrm{C}=\mathrm{O} \\
\mathrm{C}=\mathrm{N} \\
\mathrm{Cl}-\mathrm{C}=\mathrm{N} \\
\mathrm{C} \text { in aromatic ring } \\
\mathrm{CH}_{3}\end{array}$ \\
\hline
\end{tabular}

Practically in all the compounds $-\mathrm{NH}_{2}$ asymmetric stretching vibration is assigned to a peak around $3400 \mathrm{~cm}^{-1}$, while a peak around $3250 \mathrm{~cm}^{-1}$ is attributed to $-\mathrm{NH}_{2}$ symmetric 
stretching vibration. The $=\mathrm{CH}$ stretching vibration in the vinyl moiety is attributed to the absorption at $\sim 3040 \mathrm{~cm}^{-1}$. The aromatic C-H stretching frequency, as expected is observed at around $\sim 3010 \mathrm{~cm}^{-1}$. The strong absorption at $\sim 1700 \mathrm{~cm}^{-1}$ is found to be present in majority of the compounds. The absorption will have contributions from stretching of $>\mathrm{C}=\mathrm{O}$ and $>\mathrm{C}=\mathrm{N}$. The strong absorption at $1650 \mathrm{~cm}^{-1}$ have contributions from $v \mathrm{C}=\mathrm{N}, v \mathrm{C}=\mathrm{C}$ and bending of $-\mathrm{NH}_{2}$. In most of the compounds the $\mathrm{C}-\mathrm{C}$ stretching of the aromatic ring is around $1540 \mathrm{~cm}^{-1}$.

A fairly strong absorption at $\sim 1300 \mathrm{~cm}^{-1}$ is assigned to $\mathrm{C}-\mathrm{N}$ stretching. The strong absorption in the region $810-840 \mathrm{~cm}^{-1}$ is due to $\mathrm{C}-\mathrm{H}$ out of plane bending in aromatic ring. The $\mathrm{C}-\mathrm{Cl}$ stretching is attributed to the strong absorption in the region $740-720 \mathrm{~cm}^{-1}$. Compounds containing $\mathrm{O}=\mathrm{S}=\mathrm{O}$ moiety show strong absorption in the region of 1050-1200 $\mathrm{cm}^{-1}$ is due to $\mathrm{O}=\mathrm{S}=\mathrm{O}$ stretching. The $\mathrm{C}-\mathrm{H}$ bending in the vinyl moiety is seen as a strong band around $800 \mathrm{~cm}^{-1}$ in all the compounds. The compounds containing $-\mathrm{CH}_{3}$ group shows peaks due to asymmetric and symmetric bending of $-\mathrm{CH}_{3}$ group at 1475 and $1375 \mathrm{~cm}^{-1}$ respectively and absorption at $\sim 550 \mathrm{~cm}^{-1}$ in the bromo compounds is assigned to $\mathrm{C}-\mathrm{Br}$ stretching.

The synthesized compounds were screened 'in vitro' for antimicrobial activity. From the data presented in Table-3, it is clear that out of 8 imidazole compounds IMMD, IMBD, IMDM exhibited moderate inhibition against gram negative bacterial species and especially against Escherichia coli while IMBD, IMDM and IMOTD showed maximum activity against most gram negative organisms. Against gram positive organisms almost all compound of the series exhibited maximum inhibition, especially IMPD and IMBD showed highest inhibition against $B$. megaterium, while IMMD and IMDT showed good inhibition against fungal organism especially $C$. albicans. The other compounds exhibited moderate to less inhibition against fungal species, but IMMD showed good inhibition.

Table 3. Antimicrobial activity of imidazoles.

\begin{tabular}{|c|c|c|c|c|c|c|}
\hline \multirow{2}{*}{$\begin{array}{c}\text { Compound } \\
\text { code }\end{array}$} & \multicolumn{6}{|c|}{ Inhibition zone against (in mm) } \\
\cline { 2 - 7 } & $\begin{array}{c}\boldsymbol{E} . \\
\text { coli }\end{array}$ & $\begin{array}{c}\boldsymbol{P} . \\
\text { aeruginosa }\end{array}$ & $\begin{array}{c}\boldsymbol{B} . \\
\text { subtilis }\end{array}$ & $\begin{array}{c}\boldsymbol{B} . \\
\text { megaterium }\end{array}$ & $\begin{array}{c}\boldsymbol{A} . \\
\text { niger }\end{array}$ & $\begin{array}{c}\boldsymbol{C} . \\
\text { albicans }\end{array}$ \\
\hline IMMD & 16 & 13 & 25 & 27 & 15 & 19 \\
\hline IMPD & 14 & 12 & 27 & 28 & 12 & 16 \\
\hline IMBD & 20 & 17 & 28 & 30 & 16 & 17 \\
\hline IMOTD & 19 & 16 & 20 & 23 & 14 & 15 \\
\hline IMDS & 14 & 12 & 20 & 20 & 11 & 14 \\
\hline IMDM & 20 & 14 & 21 & 25 & 14 & 13 \\
\hline IMDA & 17 & 15 & 23 & 26 & 13 & 15 \\
\hline IMDT & 15 & 12 & 19 & 20 & 17 & 20 \\
\hline Streptomycin & 35 & 34 & 35 & 36 & - & - \\
\hline Imidil & - & - & - & - & 33 & 35 \\
\hline
\end{tabular}




\section{Conclusion}

The present study showed that the antimicrobial activity of newly synthesized compounds may change by introduction or elimination of a specific group. Thus, the imidazole derivatives could be powerful and elegant factor to stimulate major advances in chemotherapeutic agents of remarkable significance in medicine, biology and pharmacy.

\section{References}

1. Jain R, Jain S, Gupta R C, Anand N, Dutta G P, Puri S K, Indian J. Chem.,1994, 338, 251.

2. Mohammed A, Abdel-Hamid N, Maher F, Farghaly A, Czech. Chem. Commun.,1992, 57(7), 1547.

3. Cairns H, Cox D, Gould K J, Ingall A H, Suschitzky J L, J. Med. Chem.,1985, 28(12), 1832 .

4. Croisy-Delcey M, Coroisy A, Carrez D, C Huel, A Chiaroni, P Ducrot, E Bisagni, Jin, G Leclercq, Bioorg. Med. Chem.,2000, 8(ii), 2629.

5. Dlugosz A, Dus D, Farmaco.,1996, 51, 367.

6. Abadi A H, Brun R,Arzneimforsch Drug Res.,2003, 53, 655.

7. Grachenva T N, Loffinna D I,Khim-Farm. Zh, 1991,25, 18.

8. Tripathi R C, Saxena M, Chaudhari I M, Ind. J. Chem, 1995,34 B, 164.

9. Geiss K H, Traunt M, Ind. J. Chem.,1995, 34 B, 179.

10. Feldman J R, Oschmann L, Chem. Ber.,1954 87, 1684.

11. Mannich C, Hof W, Arch. Pharm.,1927, 265, 589.

12. Feldman J R, Wagner W C, J. Org. Chem.,1942, 7, 31.

13. Moore M B, Rapela R T, J. Am. Chem. Soc.,1946 68, 1657.

14. Atkinson R O, J. Chem.,1954, 1329 .

15. David A W, Thomas L L, "Foyes principle of medicinal chemistry", $5^{\text {th }}$ Ed., International Student Edition,2002, 819.

16. Pawar R A, Kohak A L, GogteVG, Indian. J. Chem.,1976, 14B, 375.

17. Parab R H, Chudasama C J, Patel H N, Dixit B C, Desa D J, Asian. J. Chem.,2010, 22(10), 7641.

18. Parab R H, Dixit B C,Desai D J, Asian. J. Chem.,2011, 23(6), 2725.

19. Pawar R A, Borase P B, J. Indian. Chem.,1989, 28B, 866.

20. vogel A I, "Elementary Practical Organic Chemistry", Vol.III Quantitative Organic Analysis.1958.

21. Rajput A P, Asian. J. Chem., 2004,16, 1374.

22. Arulprakash G, Sampathkumar N, Rajendran S P, Asian. J. Chem.,2002, 14, 1303.

23. Kalluary B, Gupta P, Banji B, Isloor A, Boll. Chim. Farm., 2001,140, 428.

24. Verma M, Chaturvedi A K, Choudhari A, J. Pharm. Sci.,1974, 63, 1740.

25. Upadhyay P S, Joshi S N, Baxi A J, Parikh A, J. Indian. Chem. Soc.,1991 68, 364.

26. Saravanan V S, VinothkumarS P,Gupta J, Asian. J. Chem., 2005,17 (1), 576.

27. Colle G J, Fraser G, Marmion P B , Simmons A, "Practical Medical Microbiology", $14^{\text {th }}$ Edn.,1996, Vol. 11, Churchill Livingstone: Edinburgh, 163. 


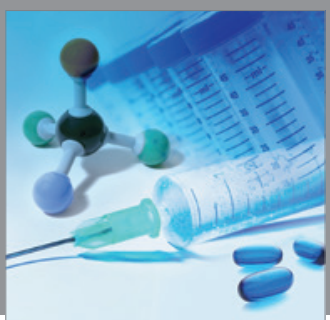

International Journal of

Medicinal Chemistry

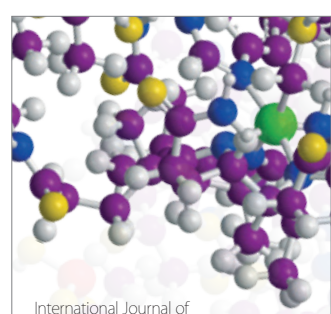

Carbohydrate Chemistry

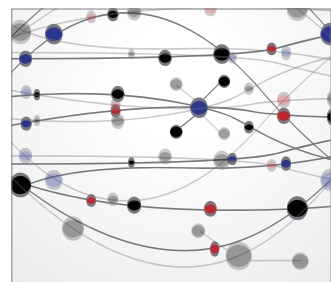

The Scientific World Journal
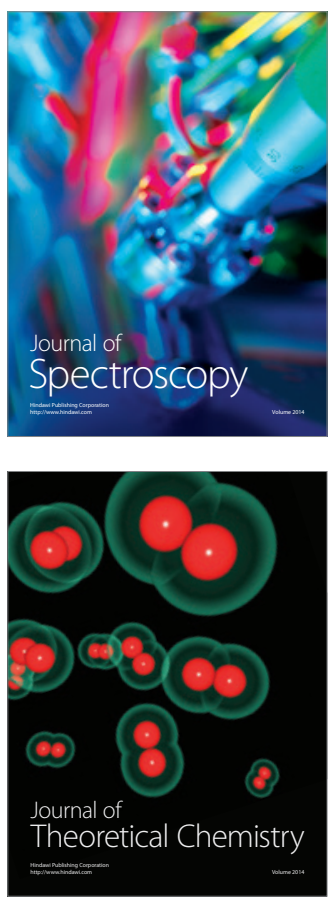
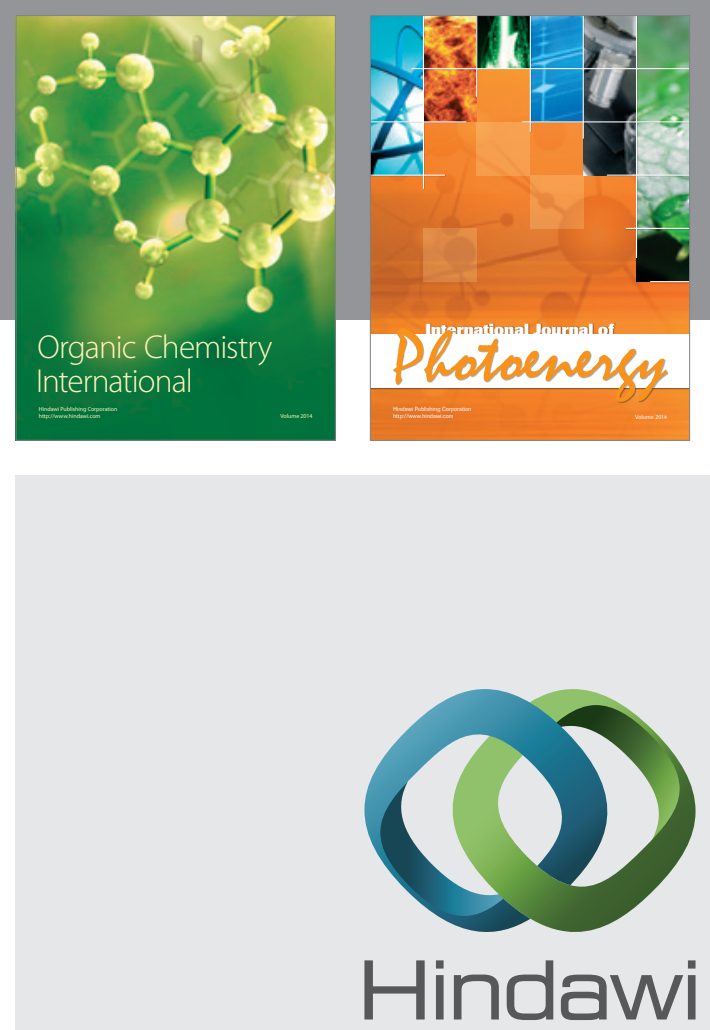

Submit your manuscripts at

http://www.hindawi.com
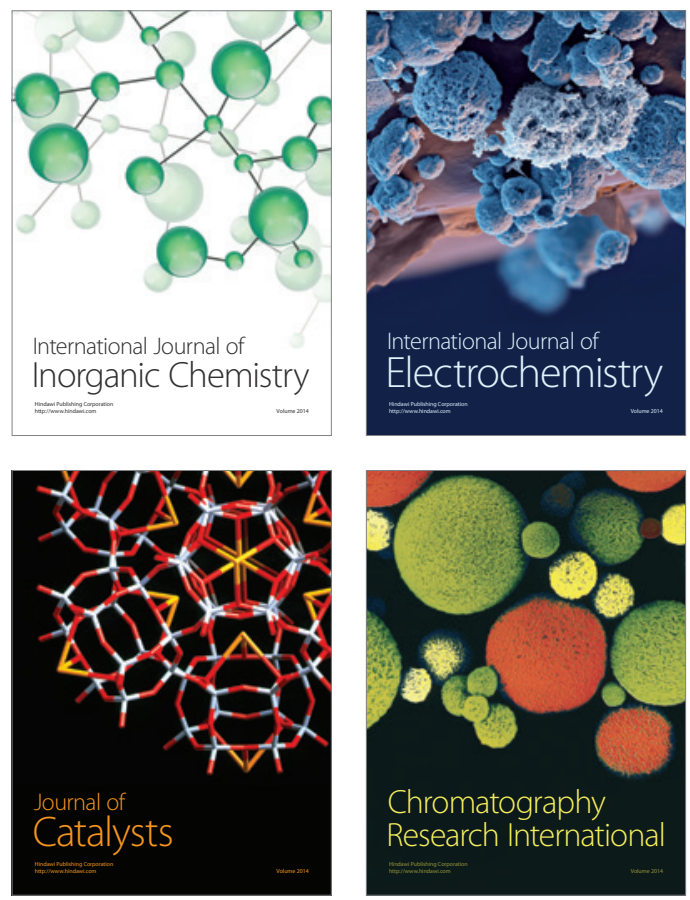
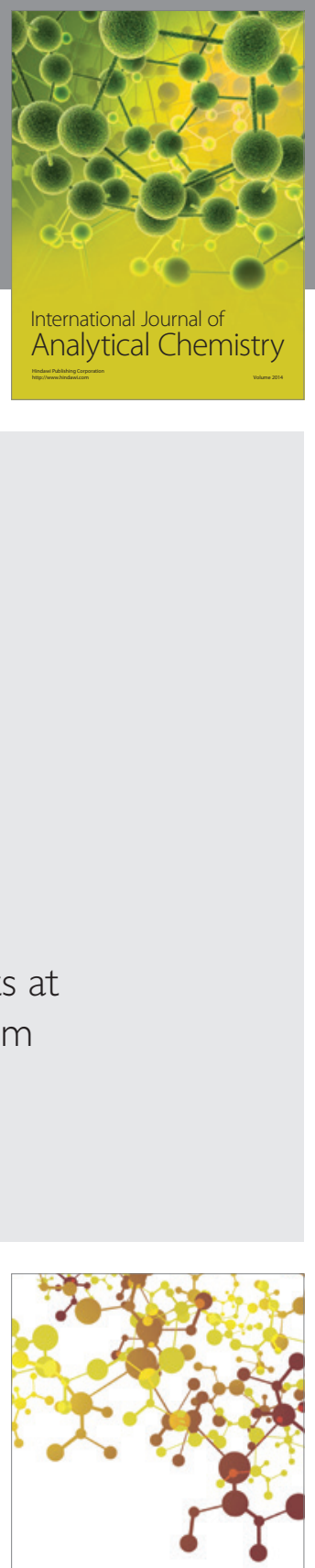

Journal of

Applied Chemistry
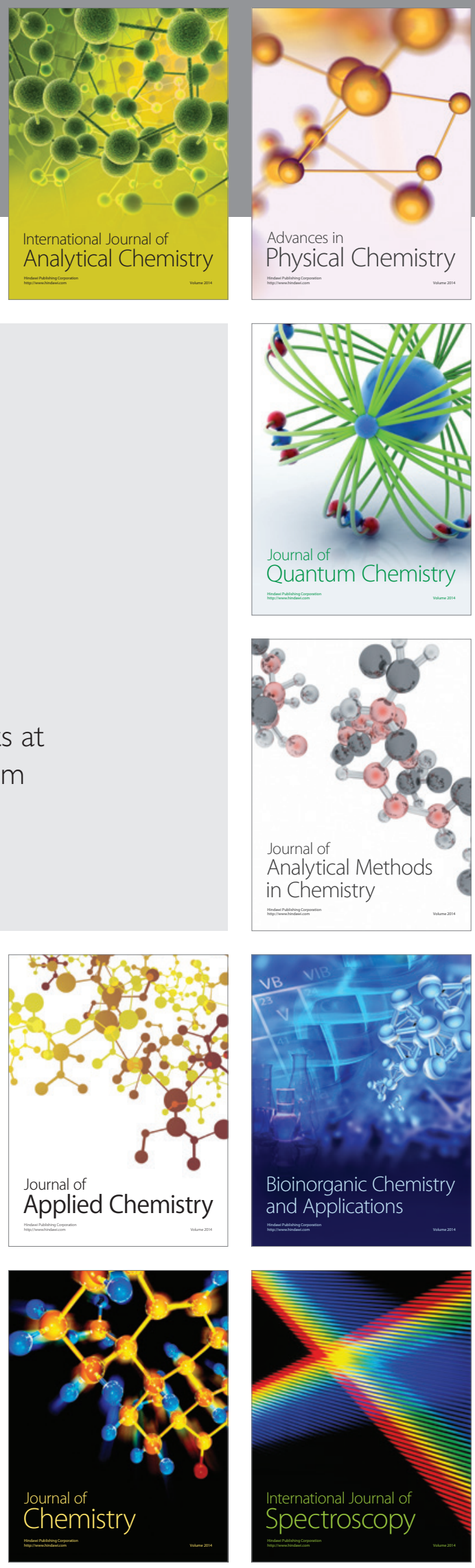